\title{
Evaluation of the effects of aerobic exercise in the aqueous environment on heart rate variability by using Poincare plot nonlinear method
}

\author{
$\underline{\text { Asgar Iranpour }}{ }^{(D)}$, LotfAli Bolboli ${ }^{2}{ }^{2}$
}

\begin{abstract}
Background and Aim: Heart rate variability used as a non-invasive method to investigate the effect of aerobics exercise on the cardiac autonomic system. The aim of this study was the nonlinear analysis of the effect of aerobic exercise in the water on the cardiac autonomic system in academic young's males.

Materials and Methods: A total of 28 young men were randomly assigned to two groups of control and aerobic exercise in water. In the pre-test period and after the training intervention, all parameters of heart rate variability were measured by examining heart rate sequences, In the pre-test period and after the training intervention, all parameters of heart rate variability were measured by examining heart rate sequences, and then the standard deviation of the recorded sequences was interpreted by using the Poincare plot method. Independent t-test and paired t-test were used to compare the differences in the research stages.

Results: Regular participation in aerobic exercise in water caused a significant (45.1 \pm 9.2 vs. $34.1 \pm 12.3)$ and standard deviation of time intervals of heart rate sequences compared to their adjacent sequence compared to the control group $(\mathrm{P}=0.03)$. The longitudinal standard deviation of time intervals of heart rate sequences compared to the pre-test $(\mathrm{P}=0.04)$ had a significant increase $(79.5 \pm 12.5$ vs. $56.9 \pm 15.8$ After transferring the absolute results to normal, the normal state of the standard deviation of time intervals of heart rate sequences compared to its adjacent sequence compared to the control group $(\mathrm{P}=0.03)$ had a significant increase $(44.7 \pm 12.05$ vs. $36.5 \pm 13.52)$. Also, the normal state of the longitudinal standard deviation of time intervals of heart rate sequences compared to the pre-test $(\mathrm{P}=0.02)$ increased significantly $(76.4 \pm 15.29$ vs. $61.3 \pm 9.32)$.
\end{abstract}

Conclusion: Performing aerobic exercise in an aqueous environment can be used as a useful training method to improve the responsiveness of the cardiac autonomic system.

Key Words: Autonomic Nervous System, Exercise, Heart Rate

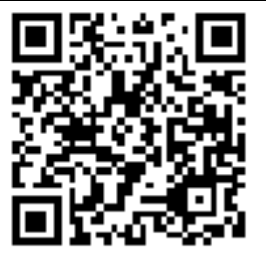

Citation: Iranpour A, Bolboli LA. [Evaluation of the effects of aerobic exercise in the aqueous environment on heart rate variability by using Poincare plot nonlinear method]. J Birjand Univ Med Sci. 2020; 27(3): 251264. [Persian].

DOI http://doi.org/10.32592/JBirjandUnivMedSci.2020.27.3.104.

Received: October 1, 2019

Accepted: May 4, 2020

\footnotetext{
${ }^{1}$ Department of Physical Education, University of Mohaghegh Ardabili, Ardebil, Iran.

${ }^{2}$ Department of Physical Education, University of Mohaghegh Ardabili, Ardebil, Iran.

Corresponding author; Department of Physical Education, University of Mohaghegh Ardabili, Ardebil, Iran Tel: +989147047033 Fax: +9831505000 Email:Iranpoursport@yahoo.com 


\title{
بررسى اثرات تمرين ايروبيك در محيط آبى بر تغييريذيرى ضربان قلب با استفاده از روش غير خطى بروئ
}

\author{
(iD) عسكر اير انيور (i)'، لطفعلى بلبلى
}

\section{جكيده}

زمينه و هدف: تغييريذيرى ضربان قلب، روش غيرتهاجمى بررسى اثر مداخله فعاليت ورزشى بر سيسته اتونوم قلبى است. هدف از ازي

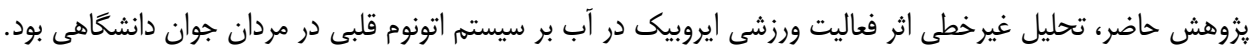

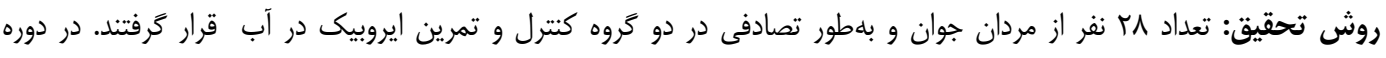

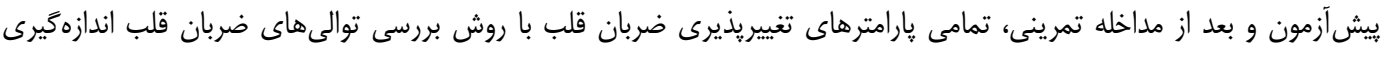

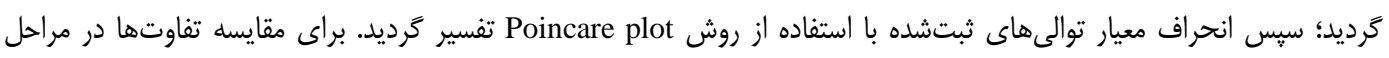

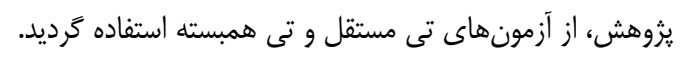

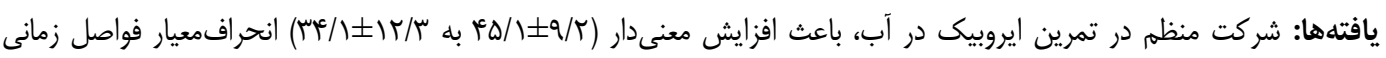

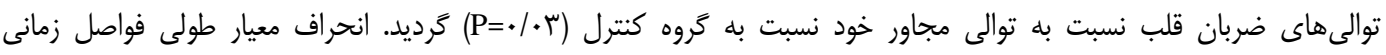

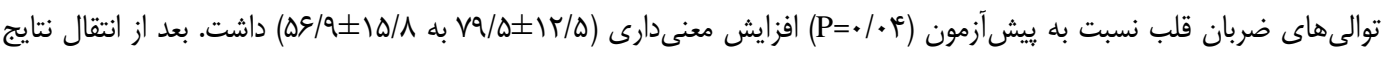

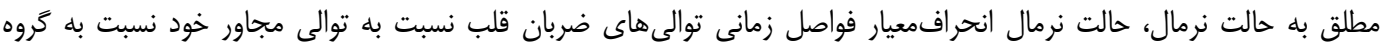

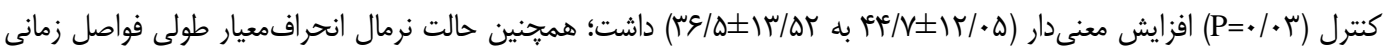

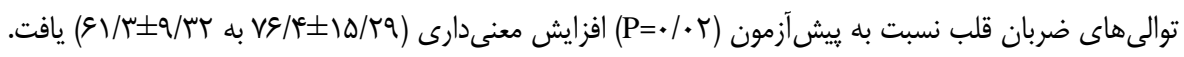

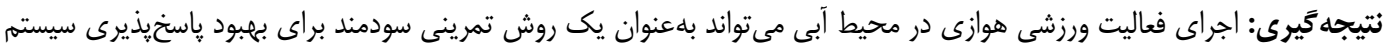

$$
\text { اتونوم قلبى مورد استفاده قرار كيرد. }
$$$$
\text { وازههاى كليدى: سيستم عصبى خودكار، فعاليت ورزشى، ضربان قلب تورد }
$$

مجله علمى دانشكاه علوم يزشكى بيرجند. وqسا!

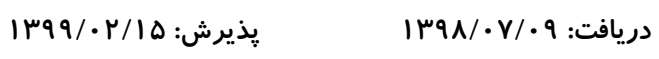

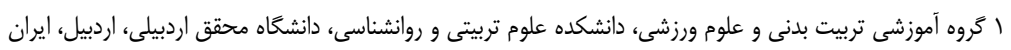

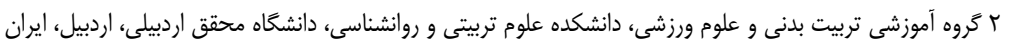
نويسنده مسؤول: كَروه آموزشى تربيت بدنى و علوم ورزشى، دانشكده علوم تربيتى و روانشناسى، دانشكاه محقق اردبيلى، اردبيل، ايران

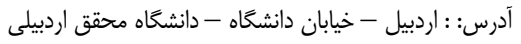

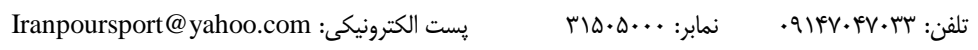


نوع سنجش كوتاهمدت و بلندمدت متفاوت خواهد بود (^). در مقدمه سنجش تغييريذيرى ضربان قلب بلصورت تكى ناشى از اثر

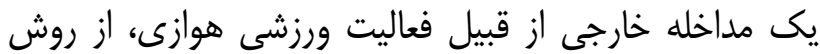
كوتاهمدت و در سنجش تغييريذيرى ضربان قلب همراه با فيا بررسى ضربانهاى نارس و بررسى اختلالات، سنجش عانش

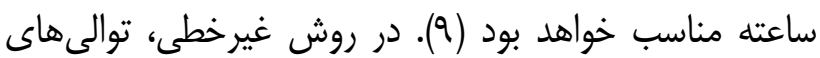
سنجش ضربان قلب بلصورت ساختارى و با ترسيم نمودار يراكندگى بلهصورت شيب خطى مورد بررسى قرار مى گيرد.

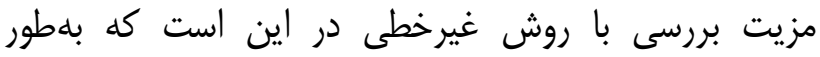

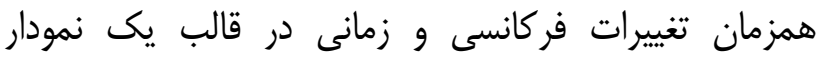

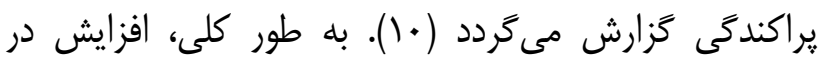
تغييريذيرى ضربان قلب ناشى از هر گونه فئر فعاليت ورزشى، بdعنوان وضعيت سلامتى مطلوب و كاهش تغييريذيرى

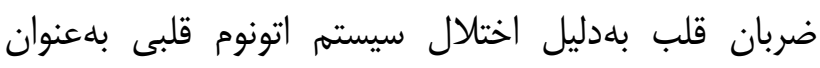
وضعيت بيمارى شناخته مىشود (1). روش Poincare plot بلهعنوان يك روش مطلوب برد براى تفسير غيرخطى تغييريذيرى ضربان قلب شناخته شده است.

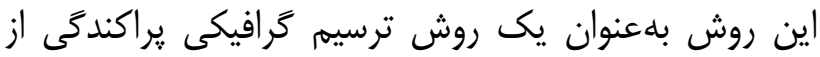

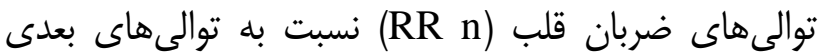

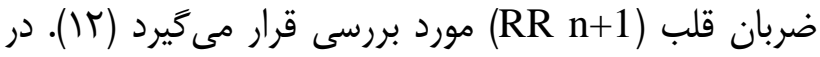
واقع در اين روش بررسى مطلق انحرافمعيار توالىهاى ضربان قلب در روش خطى صورت روت نمى ريذيرد، بلكه انحرافمعيار هر توالى ضربانهاى قلب نسبت به انحرافمعيار

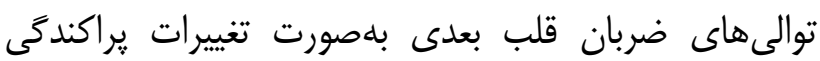

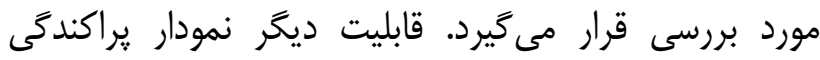
روش غيرخطى بررسى تغييريذيرى ضربان قلب، گزارش يهنا و طول تغييرات صورت $و$ (SD1) perpendicular the line of identity standard deviation along the line of identity و نسبت اين دو اينتروال (SD2)

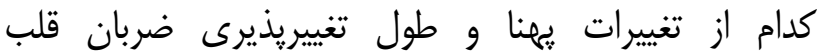

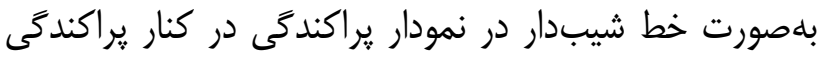

\section{${ }^{1}$ Cardiac Holter monitoring}


حاضر، معيارهاى ورود به مطالعه شامل: نداشتن سابقه بيمارى

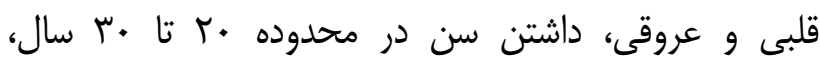

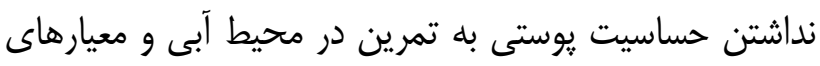

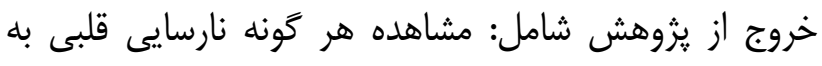

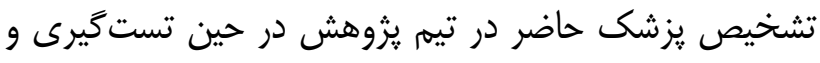

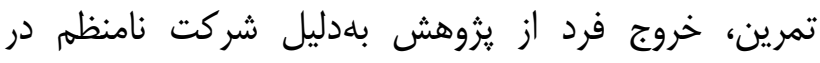

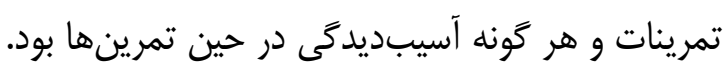

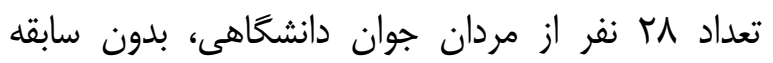

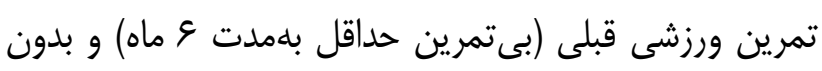

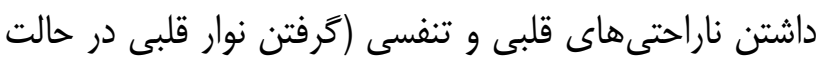

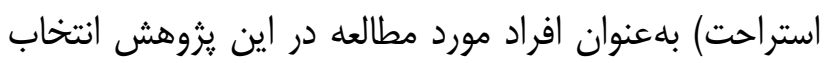

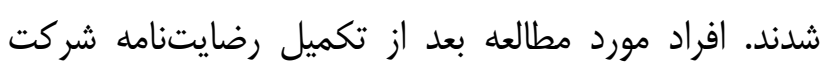

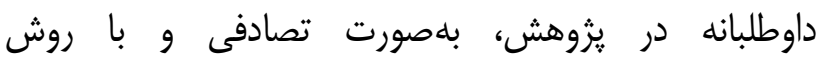

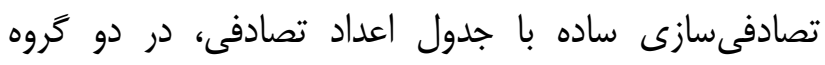
كنترل (أا نفر) و تمرين هوازى در آب (ألا نفر) قرار كرفتند. در مرحله بعد براى جلوكيرى از اثرات عوامل مخدوشئر

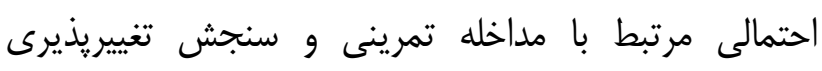

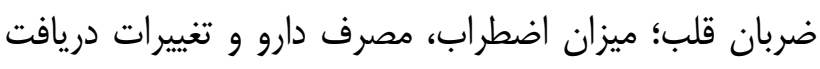

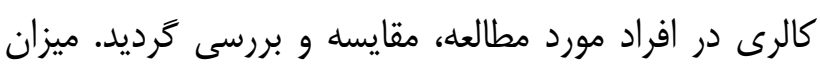

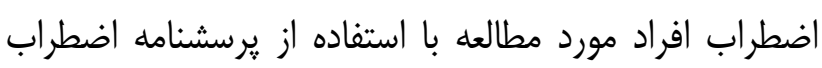
Beck

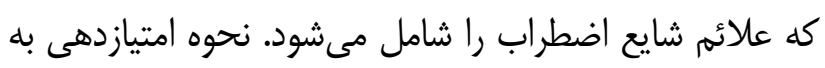

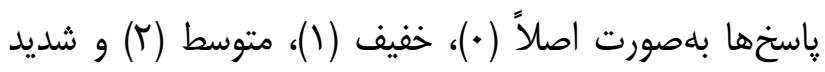

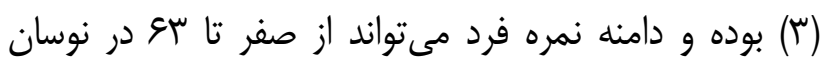

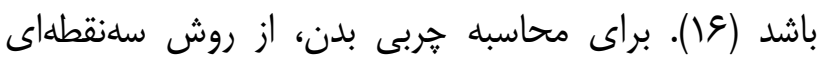

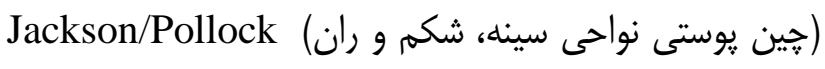
با فرمول زير استفاده گرديد (IV): . . . . . .

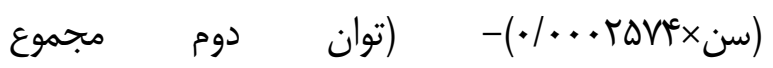

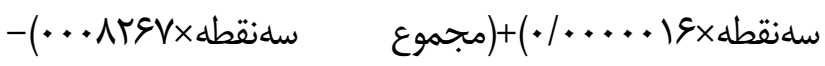

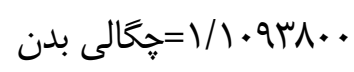

انحرافمعيارها ترسيه مى گردد. نقطه تلاقى اين دو خط

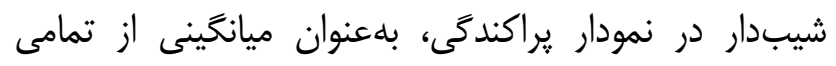

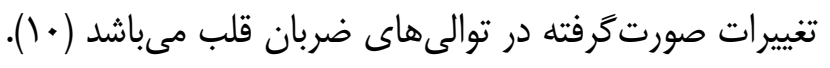

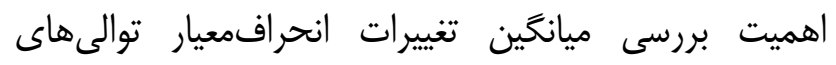
ضربان قلب در اين است كه مطلوبترين ميزان تغيير ناشى از

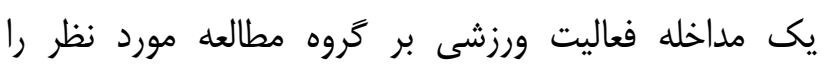

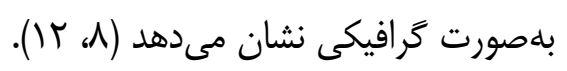
اجراى فعاليت ورزشى ايروبيك در آب بهدليل فيكي نشار هيدرواستاتيك آب، سبب جابجايى مطلوب مايعات بدن انسان

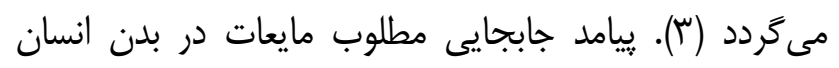

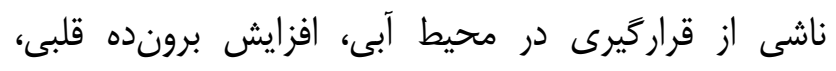

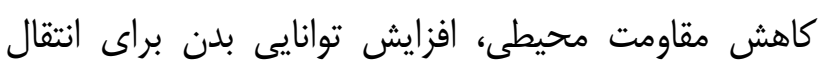

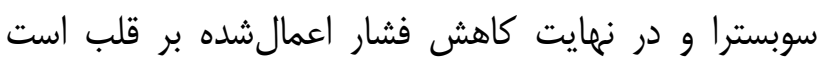

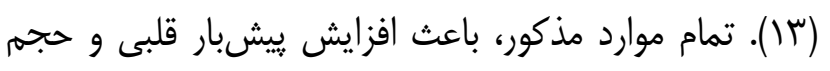

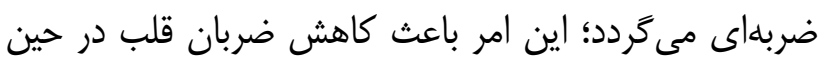

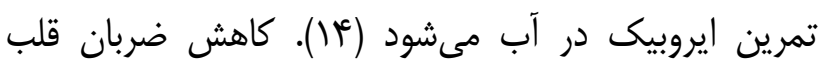
احتمالاً با تغييراتى در كرونوترويى قلبى همراه شده و مر مراكز كنترل مغزى كرونوترويى قلبى دستخوش تنظيم مجدد نقان نقان

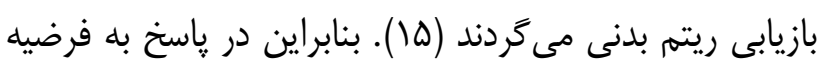

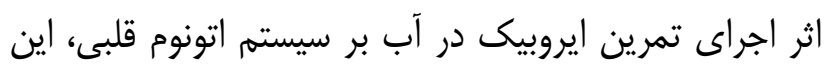

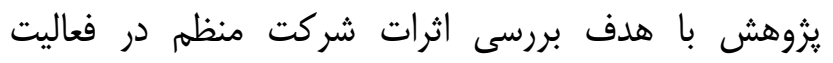

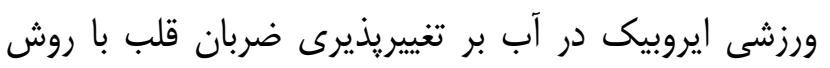
غيرخطى در مردان جوان دانشخاهى اجرا عرديد.

\section{روش تحقيق}

اين مطالعه با رعايت تمامى استانداردهاى تعيينشده توسط كميته اخلاق در يزوهش دانشخاه علوم يزشكى اردبيل

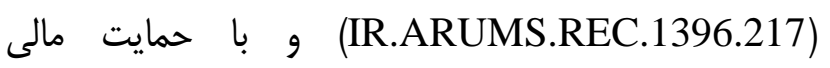
دانشگاه محقق اردبيلى به مرحله اجرا درآمد. در مرحله بعد،

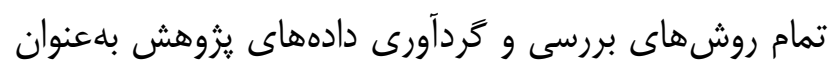
يك يزوهش كارآزمايى بالينى در مركز كارآزمايى بالينى ايران ثبت گرديد. براى مطالعه 
ضربان قلب به دقت و در همان محل برگزارى مرحله يبش آزمون، انجام شد.

مطابق با برنامه خواب و بيدارى كه در اختيار افراد مورد مطالعه قرار داده شده بود، حداقل ميزان خواب براى هر فرد فرد

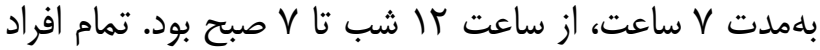

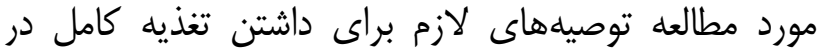
وعده صبحانه را اجرا نموده و توجيه گرديدند كه ب ساعت لَّائ قبل از اجراى فعاليت ورزشى هوازى در آب، از تغذيه سنحَين اجتناب نموده و مصرف مناسبى از نوشيدنى هاى مطلوب براي براى

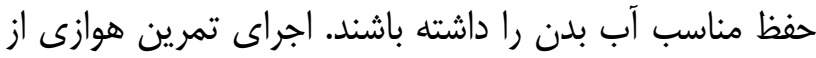

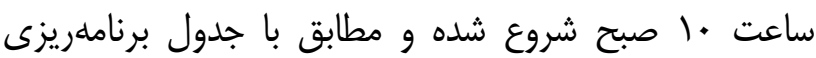

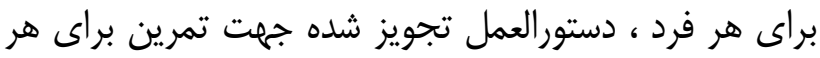

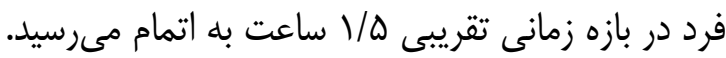

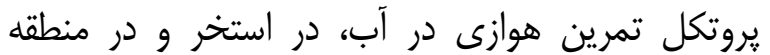

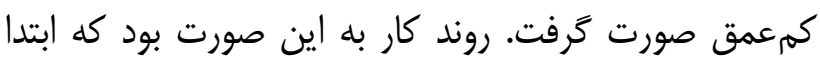

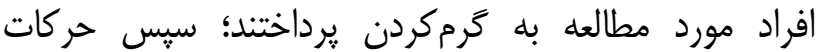

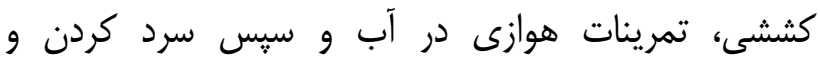

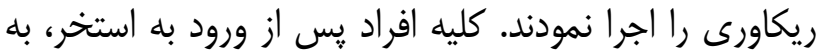
راهرفتن در يك رديف يرداختند؛ به صورتى كه تا قسمت سينه

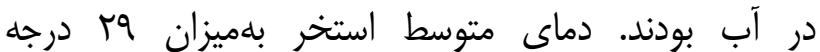

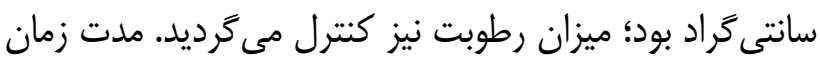

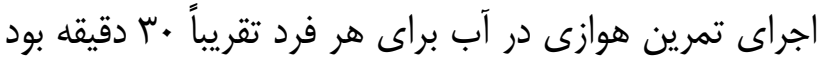

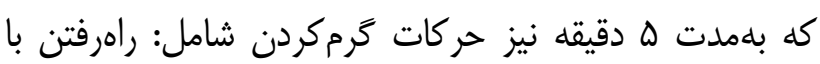

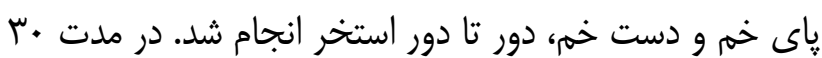

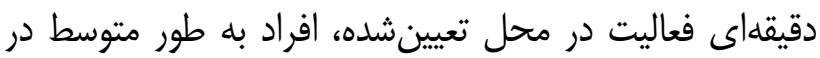

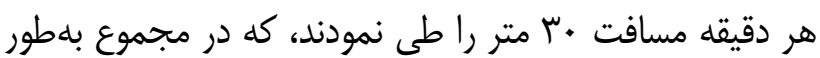

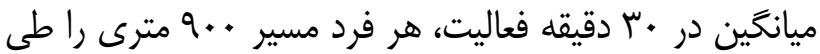

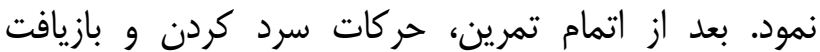

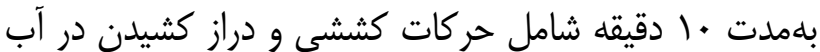
انجام شد. گروه كنترل در طول اين دوره بدون اجراى تمرين

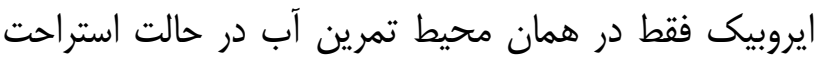

باقى ماندند.
همجنين براى برآورد كالرى مصرفى افراد مورد مطالعه از

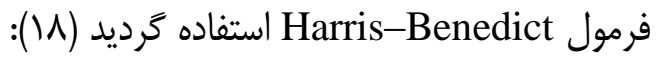

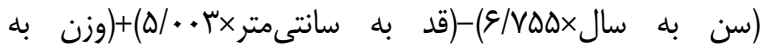
كيلو كرم

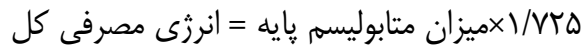

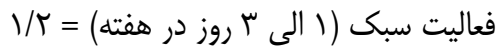

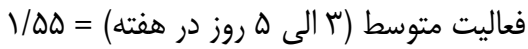

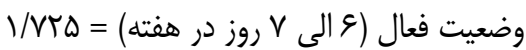

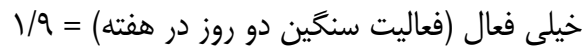

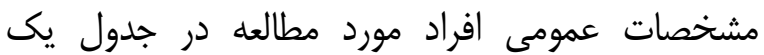

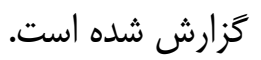

جدول ا - ميانكين و انحرافمعيار مربوط به ويزتىهاى فردى افراد

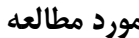

\begin{tabular}{|c|c|c|c|}
\hline sig & هوازى در تمرين & كروه كنترل & متغير \\
\hline$\cdot / V^{c}$ & $r \varepsilon / F \pm I / V I$ & $r g / 1 \pm 1 / T r$ & سن(سال) \\
\hline$\cdot 190$ & 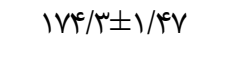 & $\mid r r / q \pm r / / r$ & قد( سانتى متر) \\
\hline.$/$ & $V F / V \pm r / V I$ & & وزن( كيلوكرم) \\
\hline.$/ 10$ & 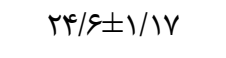 & $r \Delta / v \pm r / M$ & هربى بدن(درصد) \\
\hline .109 & $\Delta / V \pm 1 / \Lambda$ & $\Delta / r \pm 1 / r$ & اضطراب (نمره) \\
\hline- & . & . & مصرف دارو(تعداد) \\
\hline ع (ז/. & r & $r\{\Delta|/ \Lambda \Lambda \pm| \Delta \Delta / r \mid$ & كالرى مصرفى \\
\hline
\end{tabular}

كليه مراحل انتخاب افراد و اجراى يروتكل تمرين در

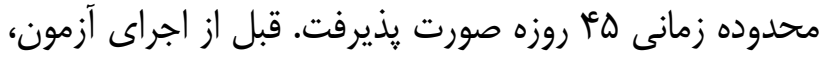

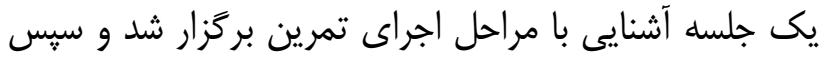

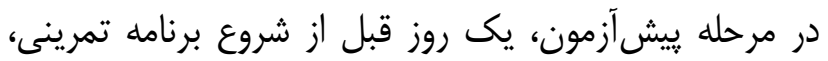

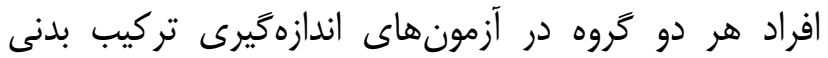

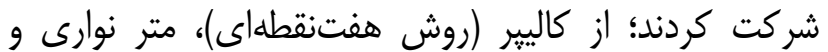

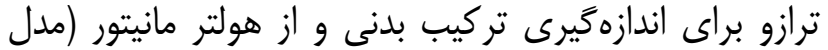
My Patch \& Vx3+

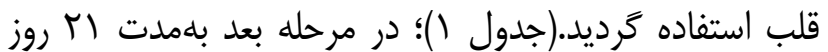
متوالى، قسمت اصلى دوره يعنى تمرين هوازى در آب انجام

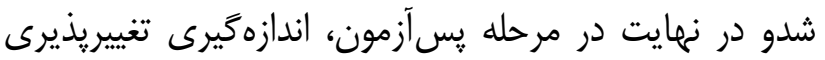




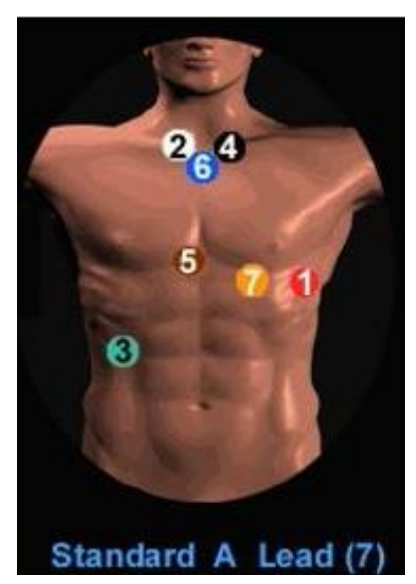

شكل ا- محل اتصال ليدهاى هولتر مانيتور قلبى مدل

My Patch \& Vx3+

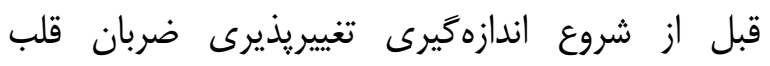

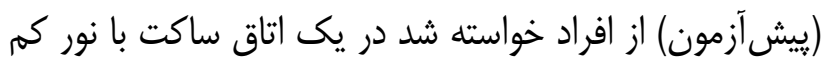

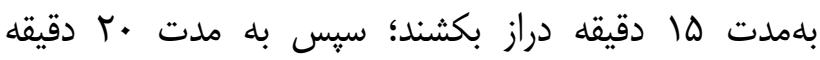
بلوسيله هولتر مانيتور، ضربان قلب استراحتى هر فرد در حالت داتل

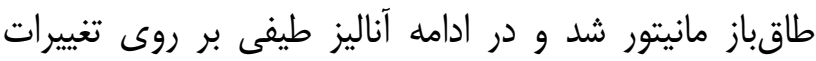

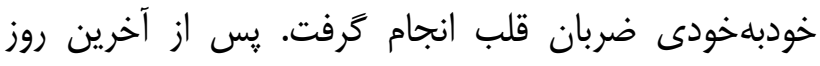

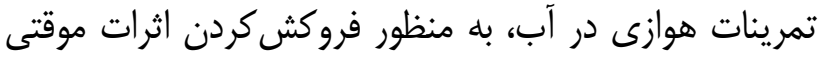

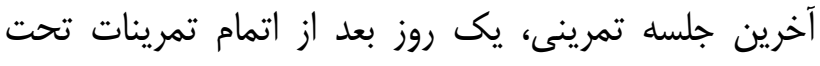

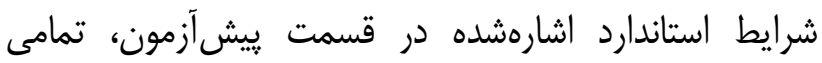

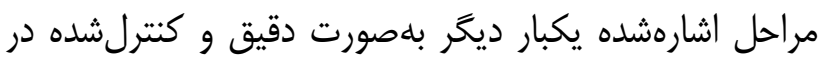
همان محيط، ثبت و به نرمافزار مربوطه منتقل گرديد. با توجه با فواصل زمانى ثبتشده بر روى نرمافزار، انحرافمعيار (SD)

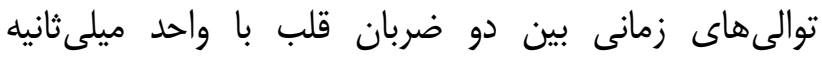
(RR n+1) نسبت به انحرافمعيار توالىهاى بعدى دمانى (RR n)

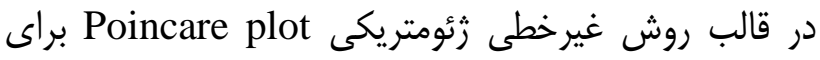
هر يك از افراد مورد مطالعه در نوار قلبى ه دقيقهاى محاسبه

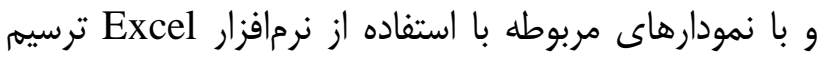

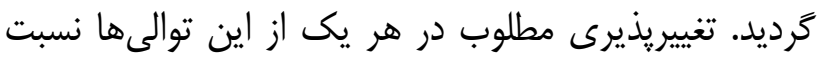

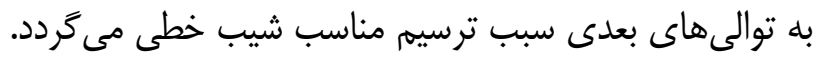

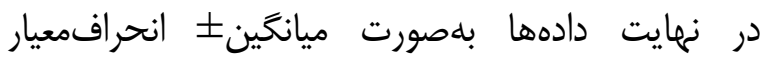
كزارش گرديد. براى تمامى تجزيه و تحليلها، نرماليته دادهها
قبل از اندازهگيرى تغييريذيرى ضربان قلب، تمام

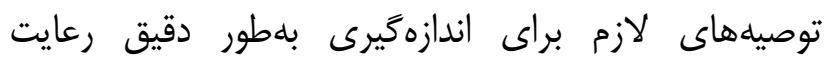

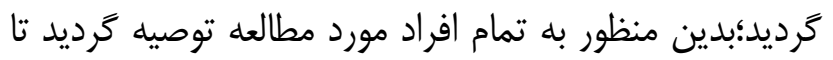

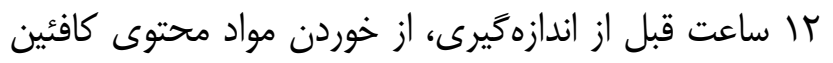

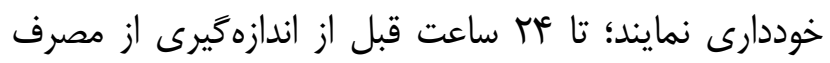

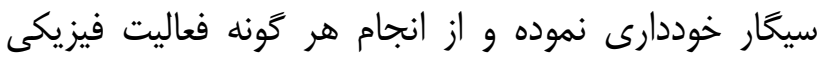

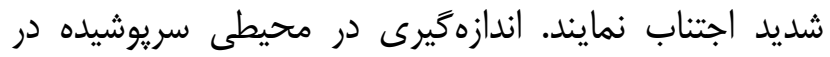

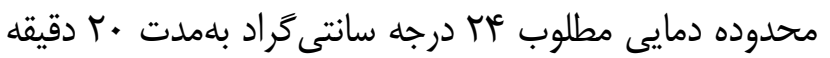

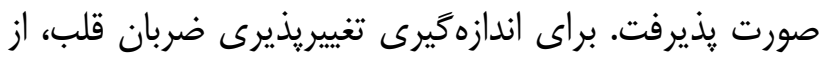
سيستم هولتر مانيتور مدل بs كشور آمريكا (نمايندگى در ايران - شركت اوسينا) استفاده شد.

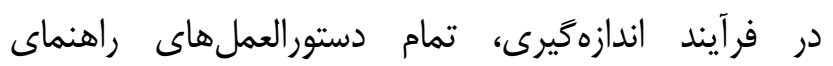

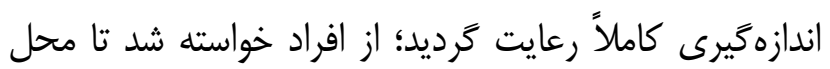

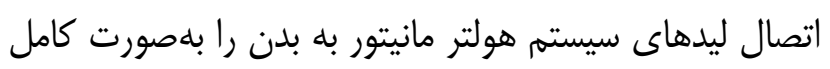

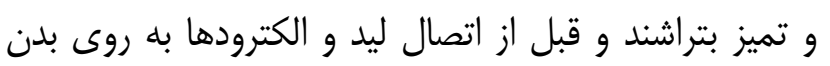

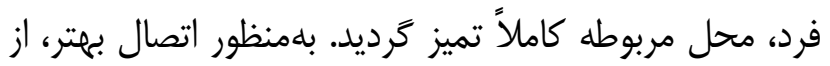

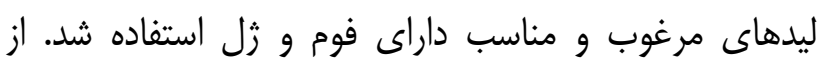

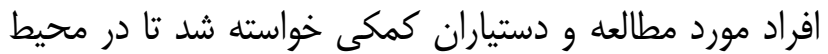

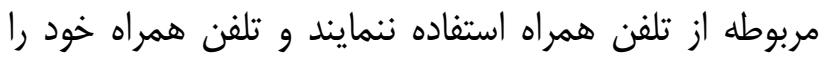

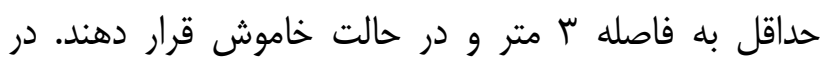

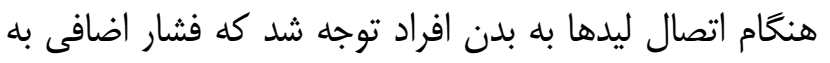

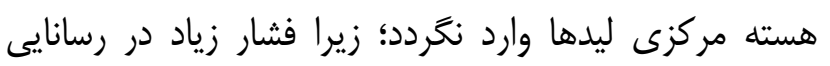
تأثير نامطلوب دارد. همجنين از افراد خواسته شد شارد تا لوازم

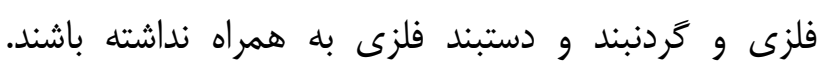

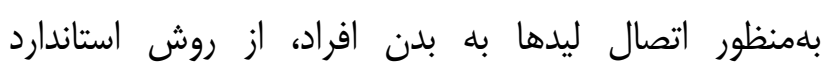
توصيهشده توسط شركت سازنده سيسته هولتر مانيتور مربوطه بله بله

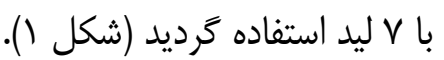


ضربان قلب نسبت به توالى مجاور خود (SD1) كرديد؛

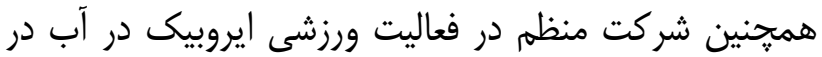

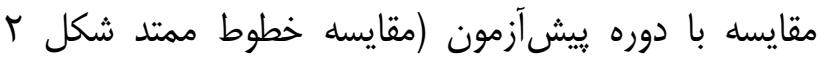

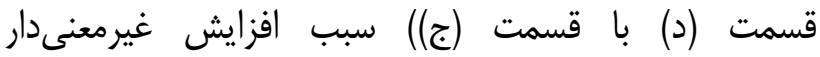
(P=•/M ) در شاخص غيرخطى انحرافمعيار فواصل زمانى توالىهاى ضربان قلب نسبت به توالى مجاور خود (SD1)

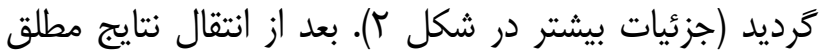

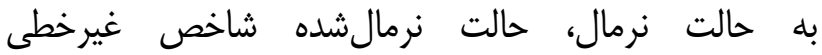

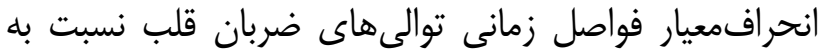
توالى مجاور خود (SD1n) نسبت به خُروه كنترل (مقايسه خطوط ممتد شكل ب قسمت (د) با قسمت (ب) (ب) افزايش

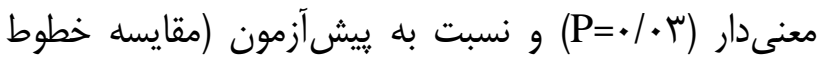

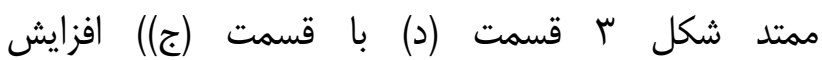

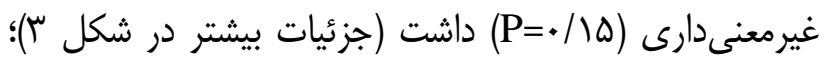
بدين معنى كه بين بررسى مطلق و نرمالشده اين شاخص

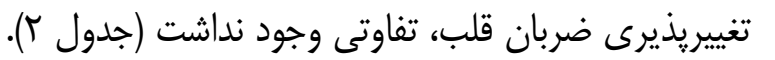

با استفاده از آزمون شاييروويلك مورد بررسى قرار گرفت. در صورت نرمالنبودن دادهها در يك متغير (در اين مطالعه فقط

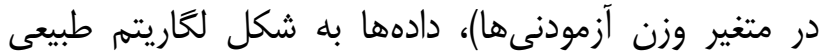

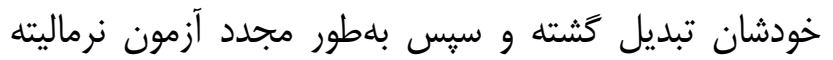

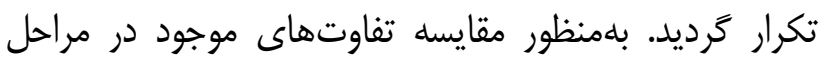

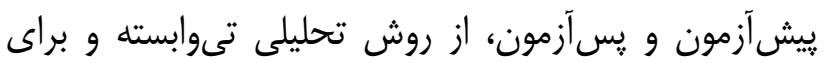

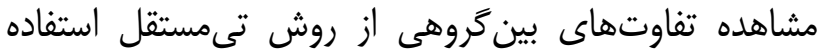

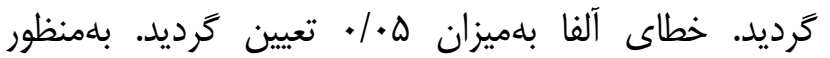

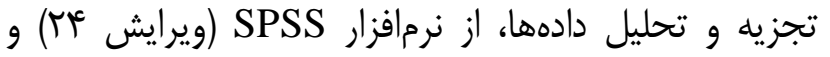

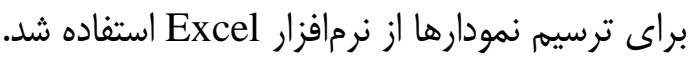

\section{يافتهها}

شركت منظم در فعاليت ورزشى ايروبيك در آب در

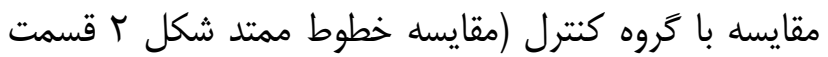

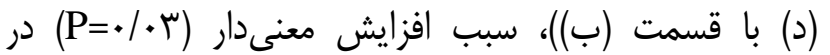
شاخص غيرخطى انحرافعيار فواصل زمانى توالىهاى جدول r- نتايج تحليل غيرخطى تغيير يذيرى ضربان قلب در تروههاى يزوهش

\begin{tabular}{|c|c|c|c|c|c|c|c|}
\hline \multicolumn{3}{|c|}{ نتايج آزمون مقايسه ميانكَينها } & \multicolumn{2}{|c|}{ تروه تمرين هوازى در آب } & \multicolumn{2}{|c|}{ تروه كنترل } & \multirow{2}{*}{ متغيرها } \\
\hline $\begin{array}{c}\text { درون كروهى } \\
\text { Sig }\end{array}$ & $\begin{array}{c}\text { بين تَروه آزمون Sig } \\
\text { Sig }\end{array}$ & $\begin{array}{l}\text { بيش تَروه آزمون Sig } \\
\text { Sig }\end{array}$ & 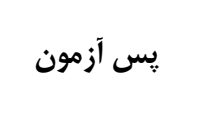 & ي ييش آزمون & يس آزمون & 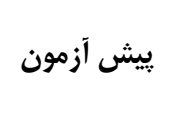 & \\
\hline.$/ 1 T$ & . r &.$/ \mu$ & $F \Delta / / \pm q / Y r \dagger$ & $r \omega / \varepsilon \pm 1 \cdot / \Gamma V$ & $\mu \Psi / I \pm I T / \mu \Delta$ & $\mathrm{r} / q \pm 1 \cdot / \mathrm{qV}$ & SD1 \\
\hline$\cdot 1 \cdot c^{4}$ & .1 .9 & $\cdot / V^{c}$ & $V Q / \Delta \pm 1 r / \Delta Q *$ & $\Delta F / q \pm|\Delta / \wedge|$ & $\Delta N / \mathcal{E} \pm I \Gamma / \Delta V$ & $\Delta S / V \pm|\Delta / r|$ & SD2 \\
\hline.$/ 10$ & r & $\cdot / 4$ & $|\varphi / V \pm| Y / \cdot \Delta \dagger$ & $r \vee / / \pm 1) / 1$ & $r \varepsilon / \Delta \pm I r / \Delta r$ & $r \omega / I \pm I \cdot / \mu c$ & SD1n \\
\hline .1 .4 & $\cdot 1 \cdot 1$ &.$/ 19$ & $v \varepsilon / \Gamma \pm 10 / r q *$ & $g / / r \pm q / r r$ & $s \kappa / \Psi \pm I r / \phi r$ & $G|/ K \pm| Q / r \mid$ & $\mathrm{SD} 2 \mathrm{n}$ \\
\hline.$/ \cdot V$ &.$/ 10$ & .1 .9 & $\cdot / \Delta \mathrm{V} \pm \cdot / \Delta$ & $\cdot / 8 \cdot \pm \cdot / V$ & $\cdot / \Delta S \pm \cdot / V$ & $\cdot / \Delta \mathrm{V} \pm \cdot / \Lambda$ & $\mathrm{SD} 1 / \mathrm{SD} 2$ \\
\hline
\end{tabular}

تفاوت معنى دار بين تحروه كنترل و تجربى (†)، تفاوت معنىدار نسبت به بيث آزمون (**)، SD1: انحراف معيار آنى اينتروال ضربه به ضربه

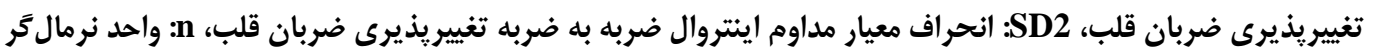


مجاور ضربان قلب (SD1) نسبت به نقطه ميانكين فواصل

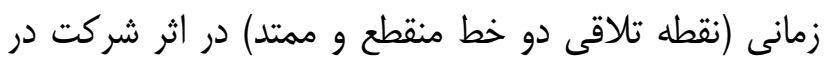

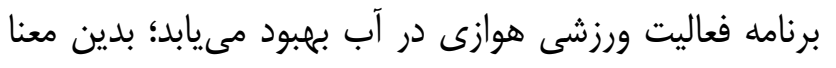

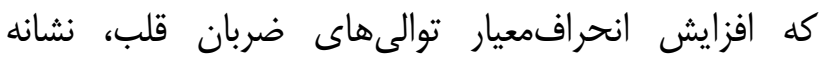

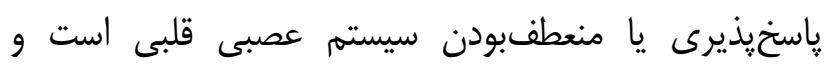

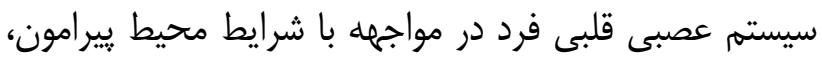

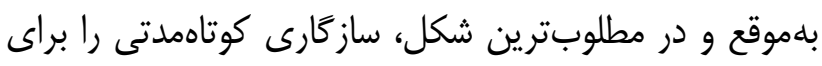

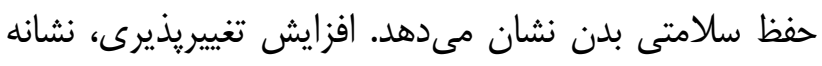

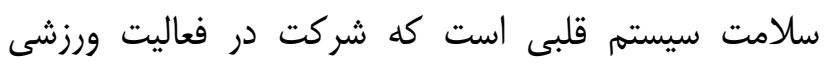

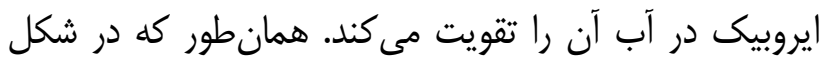

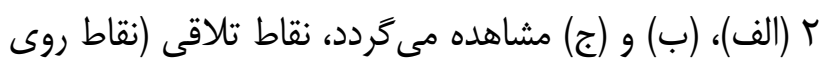

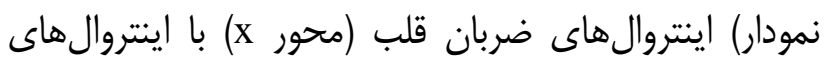

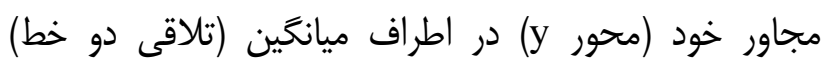

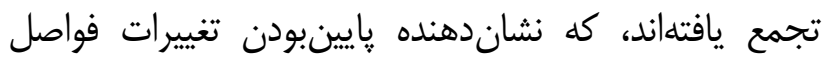

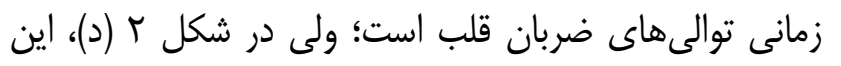
يراكندگى نشاندهنده تغييرات توالى هائى ضربان

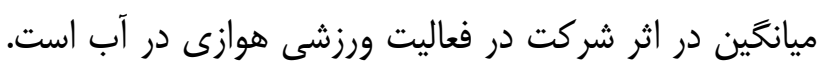

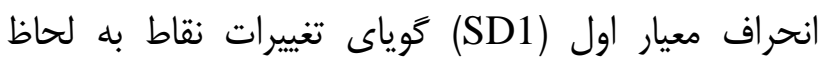

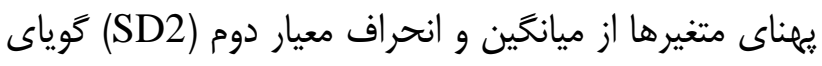
تغييرات نقاط به لحاظ طول متغير ها از ميانكين است.
انحرافمعيار طولى فواصل زمانى توالىهاى ضربان قلب

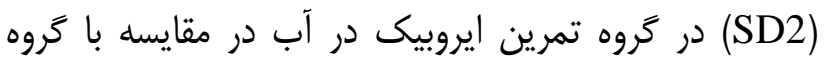

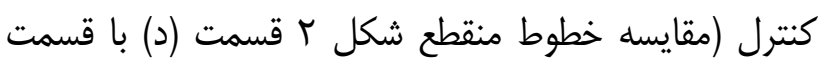

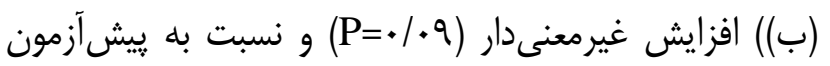

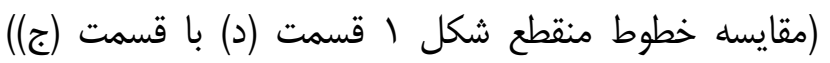

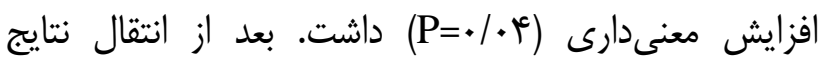

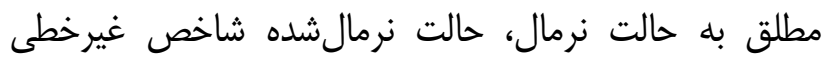

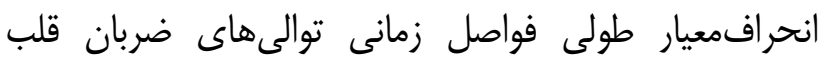

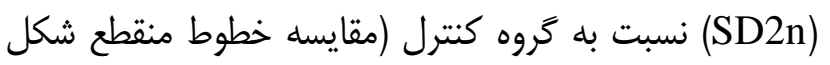

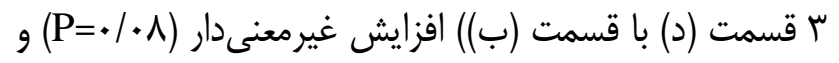

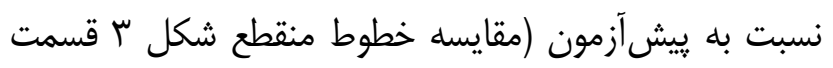

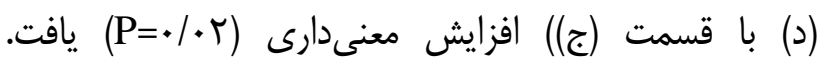

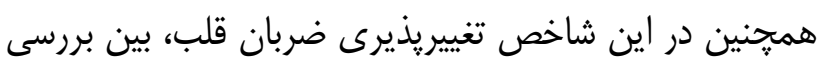

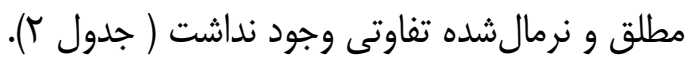

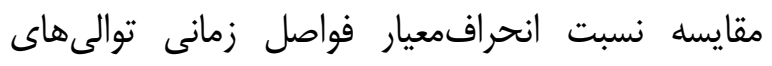

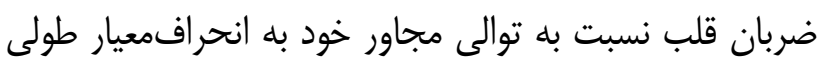

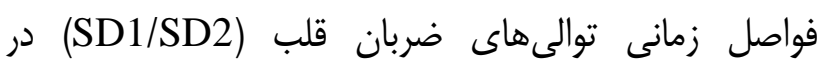

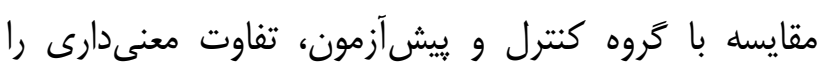

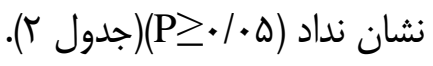
بررسى تغييرات ايتتروالهاى ضربان قلب (فواصل زمان زمانى بين موجهاى R) نشان داد كه مقادير انحرافمعيار توالىهاى (فيتران 

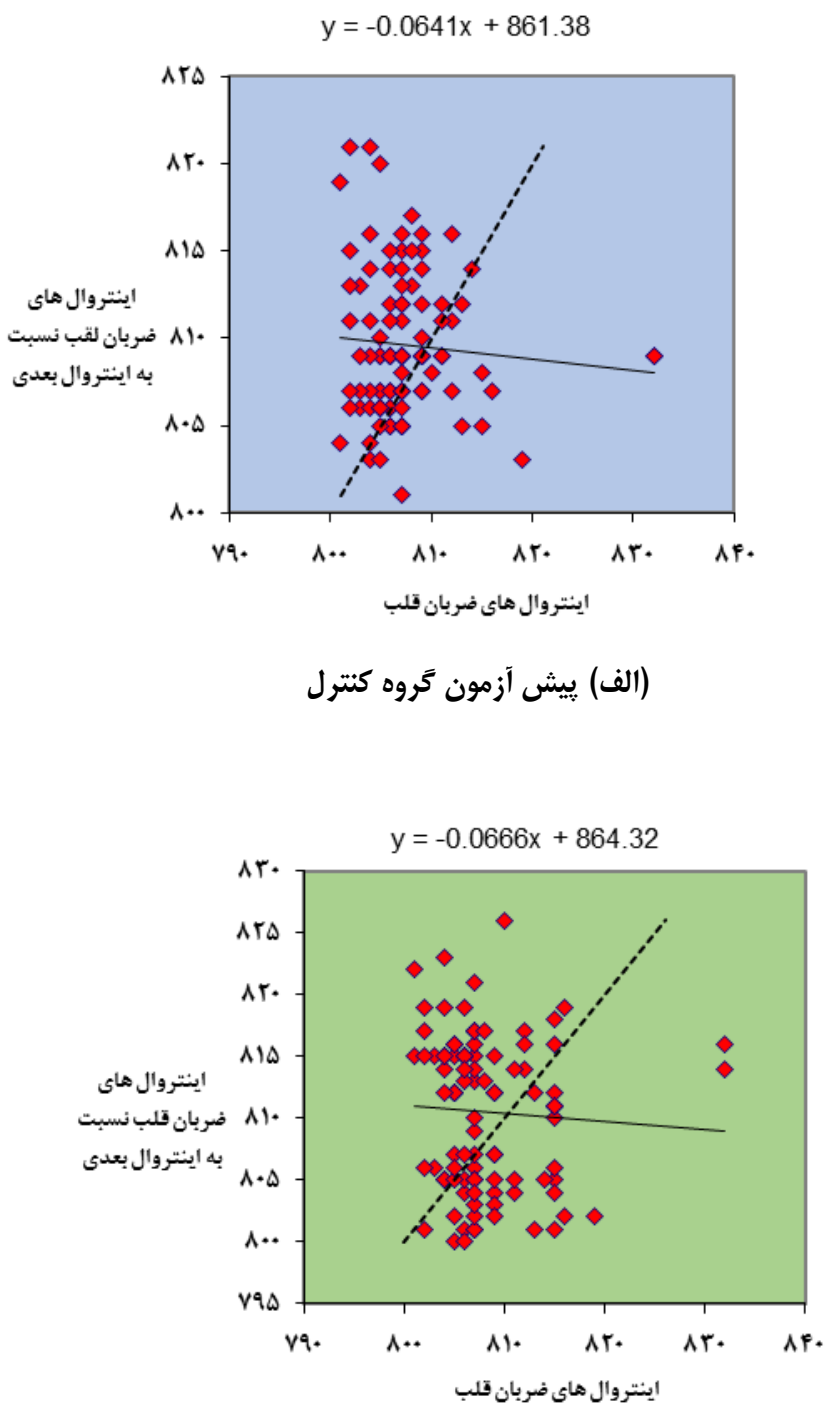

(ج) بيش آزمون تَروه تمرين

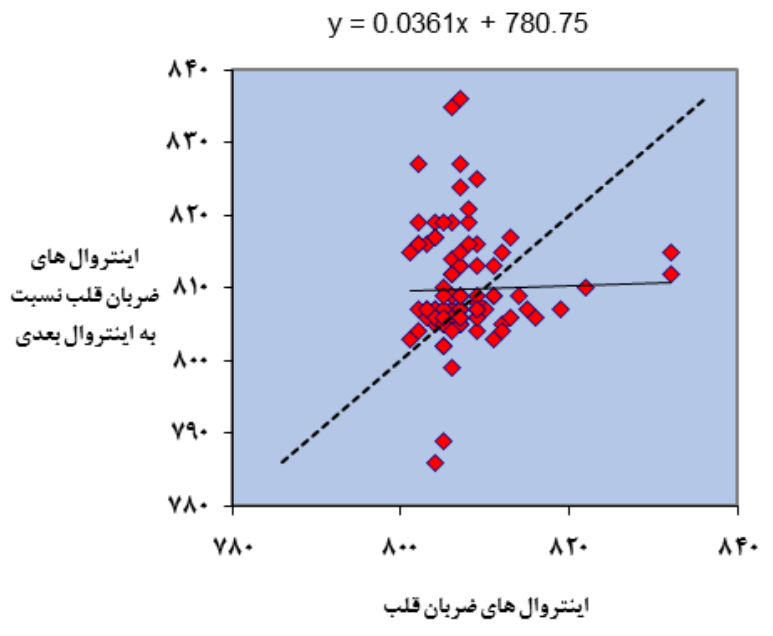

(ب) يس آزمون تروه كنترل

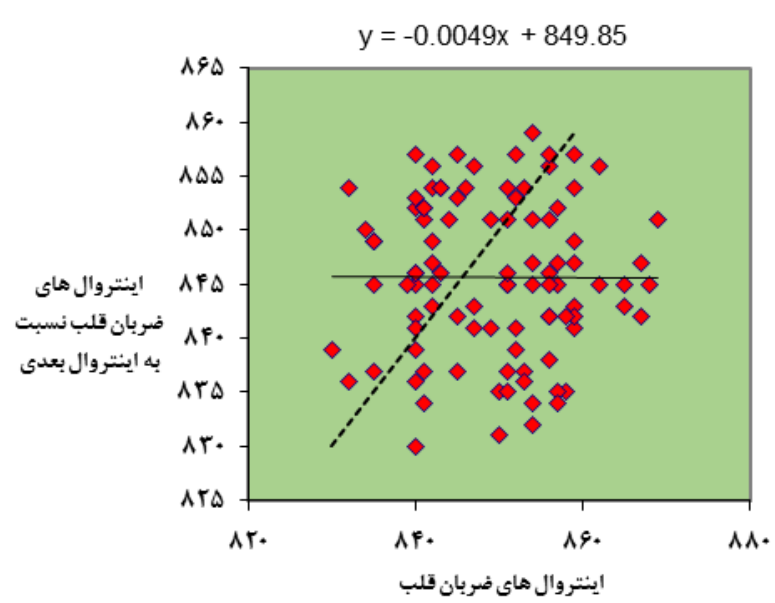

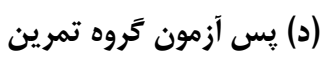

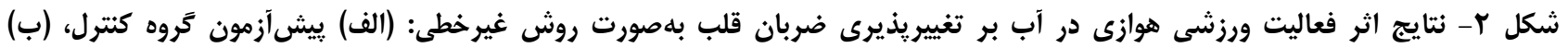

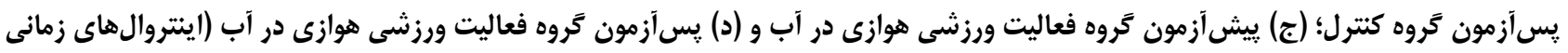

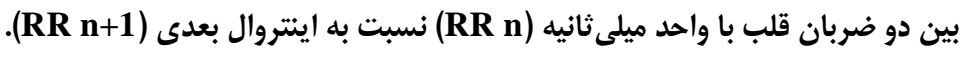




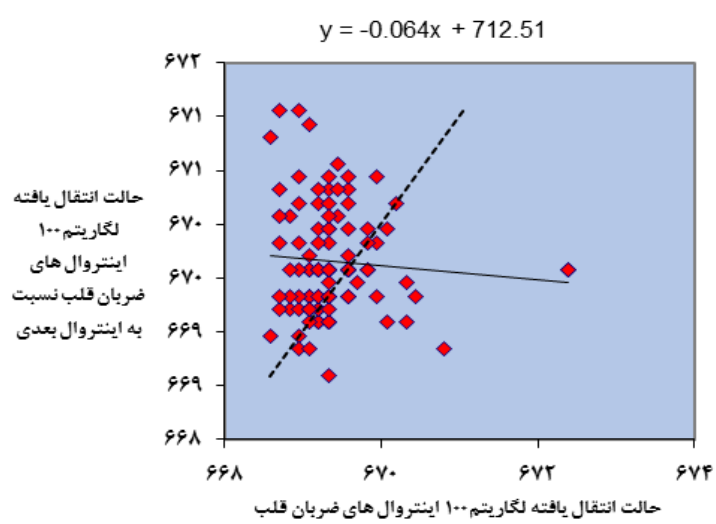

(الف) يبشآزمون تَروه كنترل

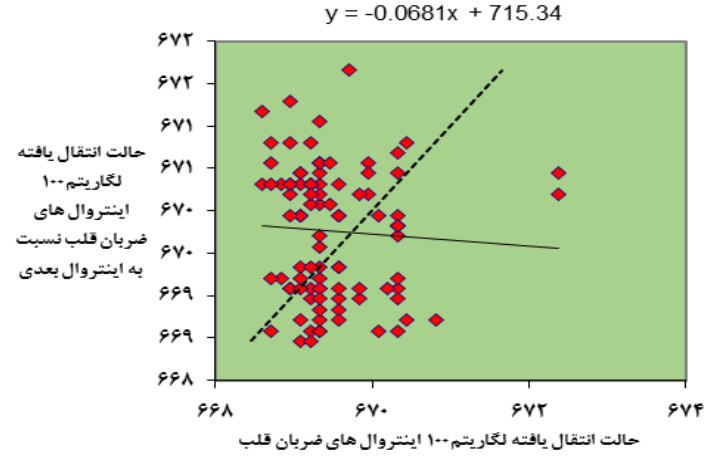

(ج) يیشآزمون تَروه تمرين

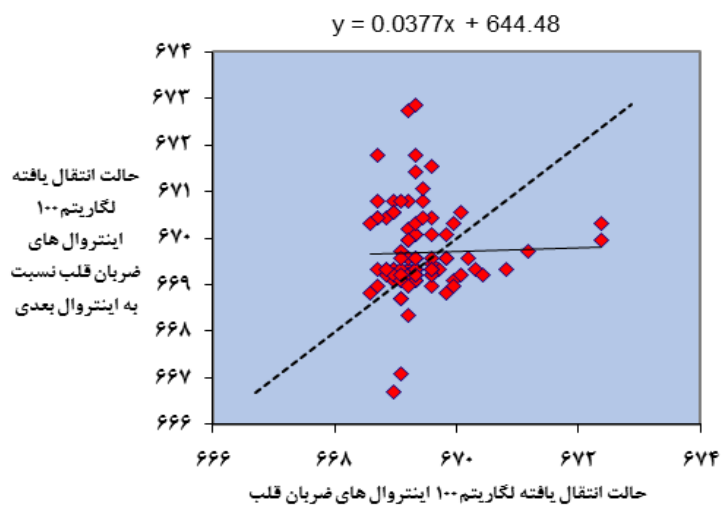

(ب) بِ آزمون تروه كنترل

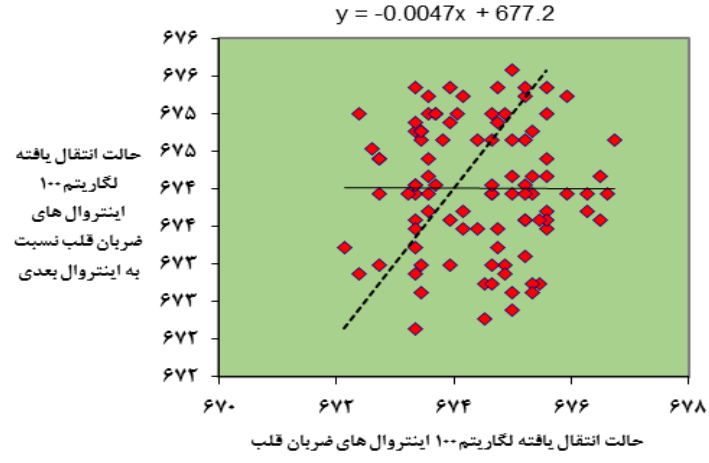

(د) بسآزمون تروه تمرين

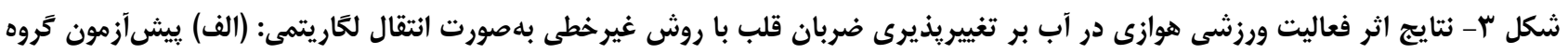

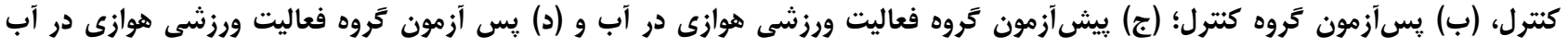

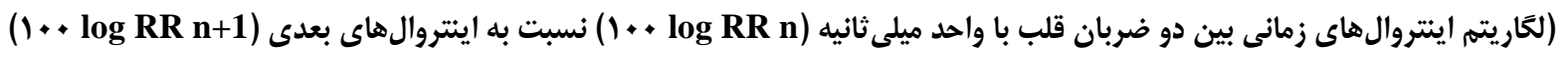

مىتوان از نتايج ساير مطالعات نيز بهرهمند گرديد. Perini و

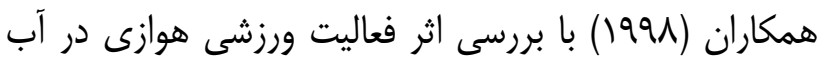

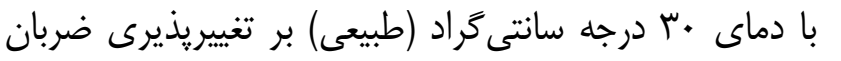

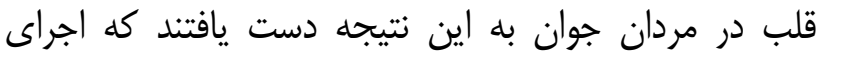

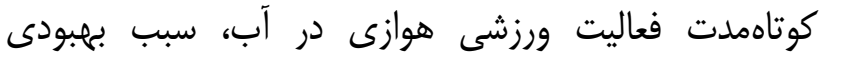
معنىدار در تغييريذيرى ضربان قلب مى گردد (•(1). مطالعه Perini

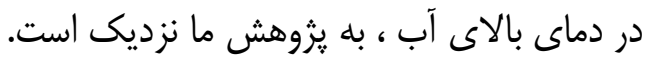
در يزوهش حاضر مشخص شد كه ميزان انحرافمعيار

كاهش مقاومت عروق محيطى، اولين ييامد ناشى از فشار

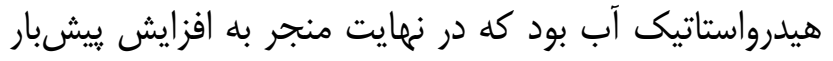
قلبى و كاهش بار كارى وارده بر قلب گرديد. بيشتر مطالعات

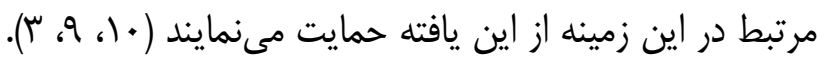
نتايج يثوهش حاضر نشان داد كه اجراى فعاليت ورزشى إنى

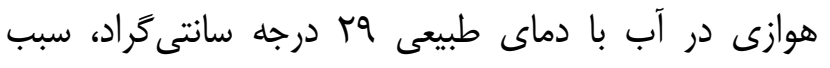

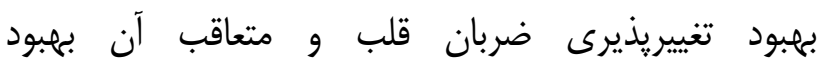
ياسخيذيرى سيسته اتونوم قلبى گرديد. در تكميل اين يافته 
يثروهش ما نشان داد كه نسبت به دوره بيش آزمون، شركت در فعاليت ورزشى هوازى در آب، بلهطور معنىدارى موجب بهبودى تغييريذيرى ضربان قلب و عملكرد بهتر سيسته

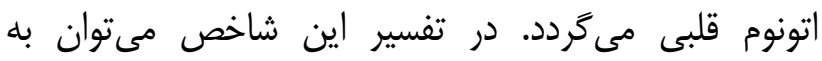
بررسى شاخصهاى زمان محور تغييريذيرى ضربان قردي

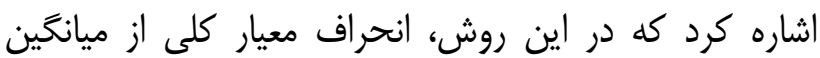

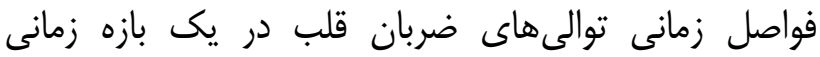

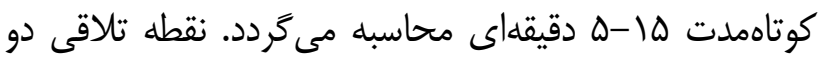
خط برازش انحرافمعيار توالىهاى مجاور و وانحرافمعيار توالىهاى طولى بر روى نمودار بلهعنوان نقطه ميانكَين فواصل زمانى توالىهاى ضربان قلب شناخته مى شودد. تغييرات

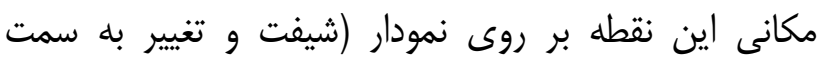

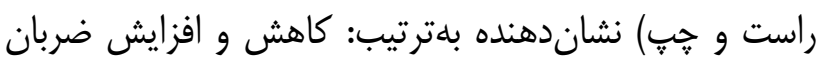

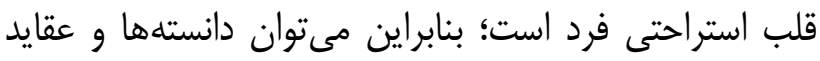
رايج قبلى درباره اينكه با شركت در فعاليت ورزشىى تعائ تعداد ضربان قلب استراحتى كاهش مئى ايابد را با با اضافهنمودن

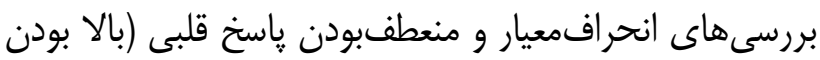
تغييريذيرى ضربان قلب) در كنار بالا بودن آمادكى قلبى البى (يايينبودن ضربان قلب استراحتى) بهعنوان دو مزيت جدانانانه

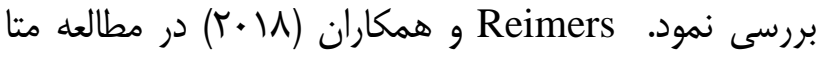
آناليز بركرفته از 191 مطالعه موردى در زمينه تأثير فعاليت ورزشى هوازى بر ضربان قلب استراحتى به اين نتيجه رسيدند

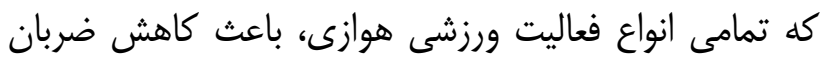

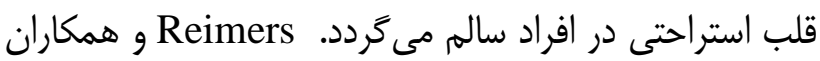

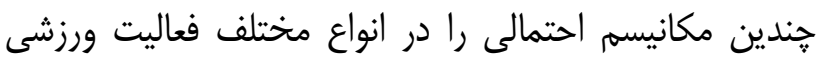

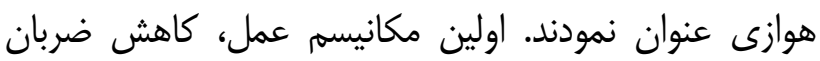

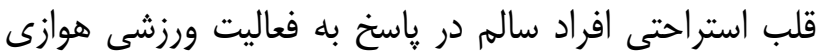

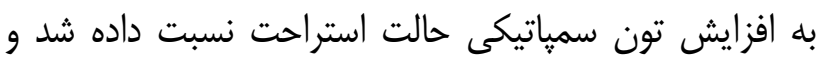

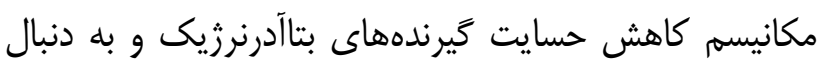

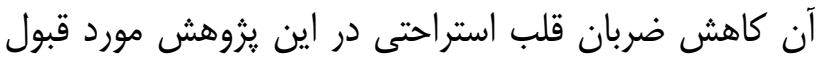

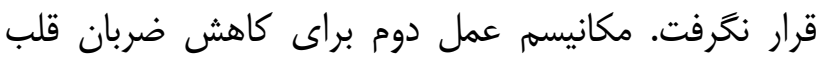
استراحتى متعاقب فعاليت ورزشى هوازى منظم، كاهش ذاتى دانى
تغييرات فواصل زمانى توالىهاى ضربان قلب نسبت به توالى مجاور خود در مقادير عددى مطلق (SD1) و نرمال (SD1n)

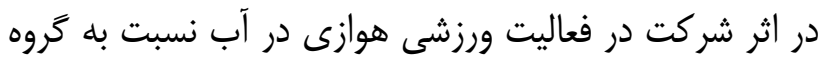
كنترل افزايش معنى دارى داشت؛ بدين معنى كه يكسان نبون ديودن

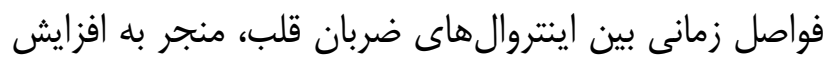

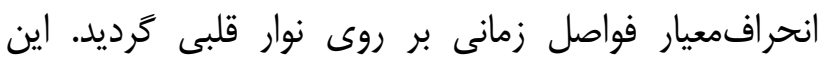

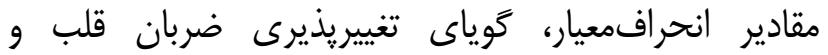
سازكارى سريع قلب با تغييرات محيط ييرامون است. دري

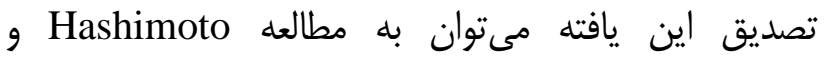

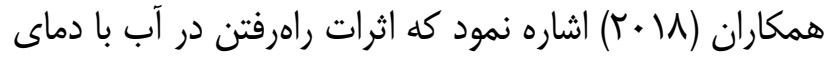

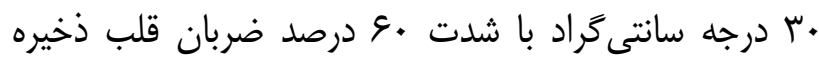

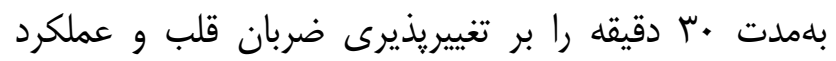
اندوتليالى عروقى را در مردان جوان سالم مورد بررسى قرئ قرار دادند. در اين مطالعه كزارش شد كه در دران مقايسه با شرايط

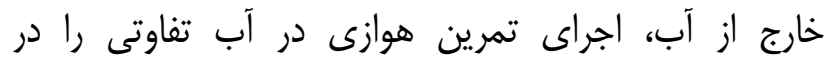

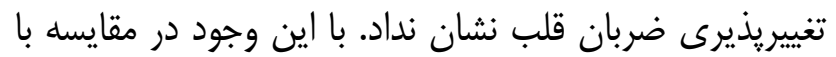

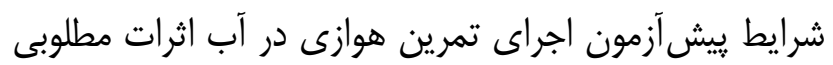

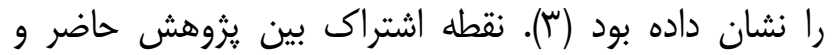
مطالعه Hashimoto و همكاران، نزديكبودن شرايط تمرين

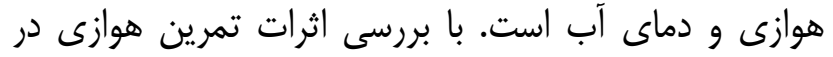
آب بر تغييريذيرى ضربان قلب در دو مطالعه مىتوان ائ تران

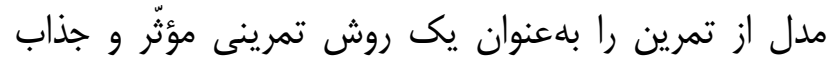

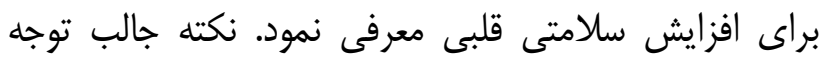

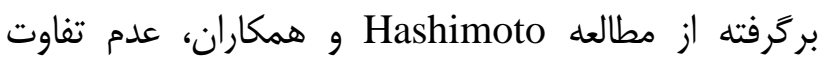

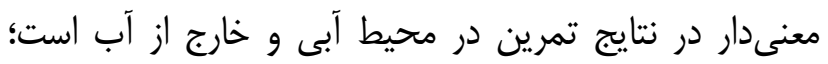

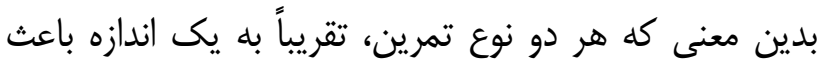

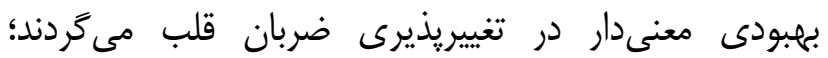

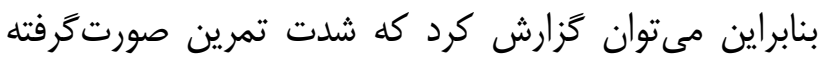

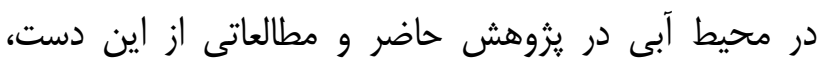

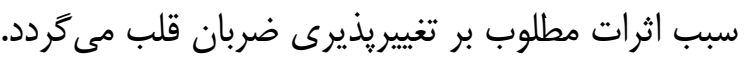

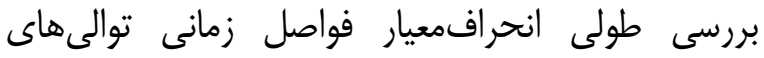

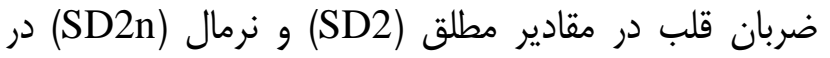




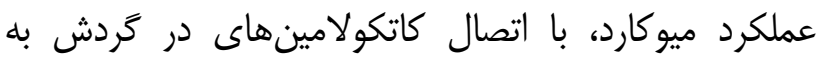

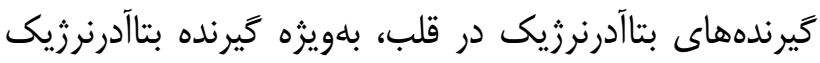

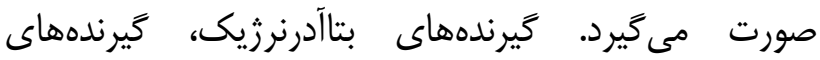

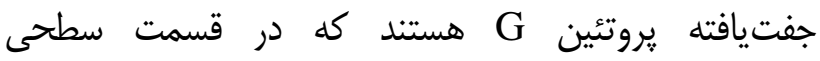

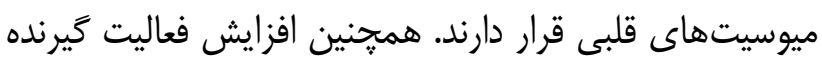

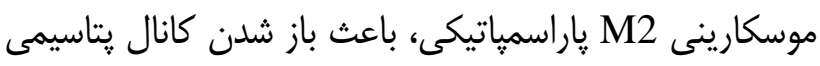

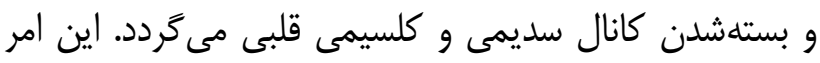

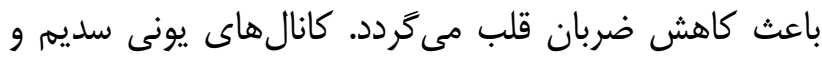

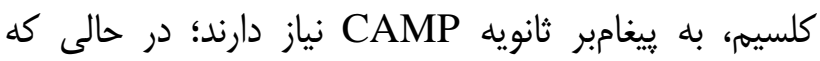

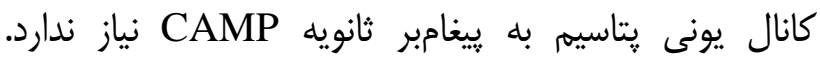

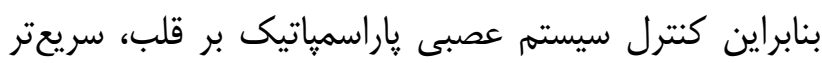
از سيسته عصبى سمياتيك است (I) (r).

\section{نتيجه كيرى}

اجراى فعاليت ورزشى هوازى در آب با دماى طبيعى (

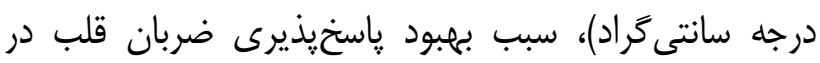

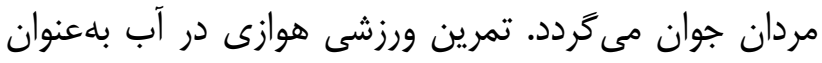

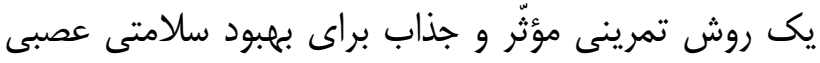

$$
\text { قلبى در اين گروه سنى معرفى مى مَردد. }
$$

\section{تقدير و تشكر}

اين يزوهش بركرفته از رساله دكترى فيزيولوزى ورزشى

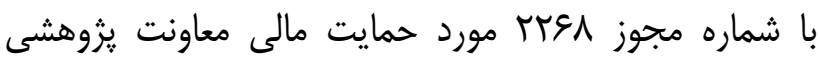

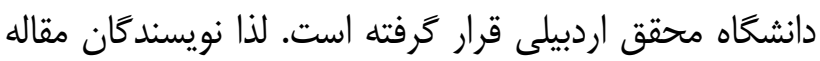

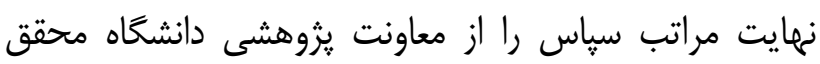
اردبيلى دارند.

\section{تضاد منافع}

نويسندكان مقاله اعلام مىدارند كه هيج كَونه تضاد منافعى در يزروهش حاضر وجود ندارد.
ضربان قلب عنوان كرديد كه مكانيسمهاى دقيق اين عمل در اين يثوهش نامعلوم ذكر شد (1) (1). تغييرات عصبى قلبى بيشتر، با بازخوردهاى منفى باتى

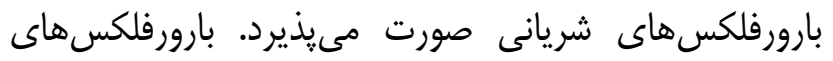

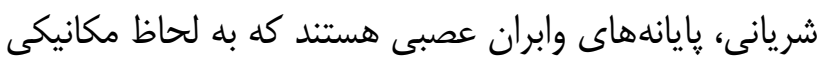

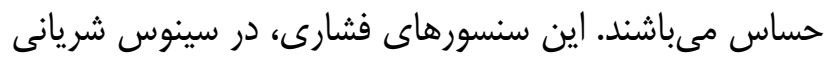

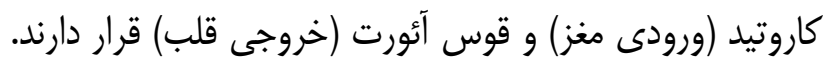

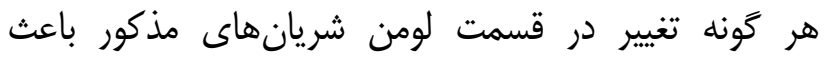

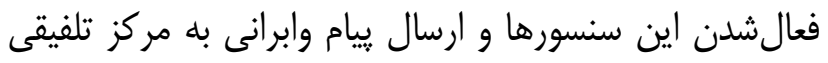

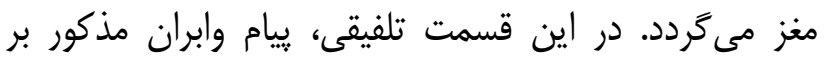

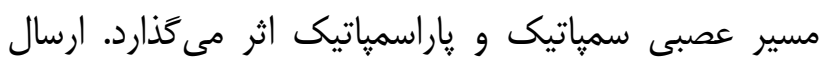

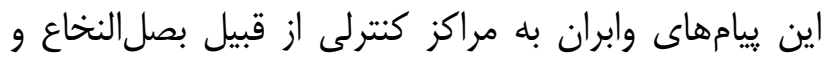

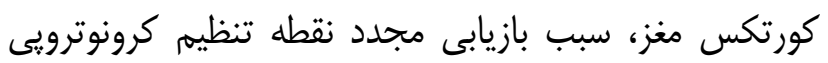

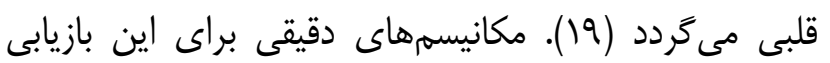

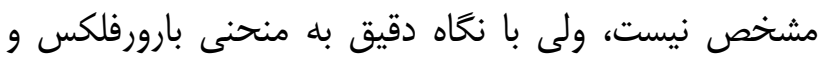

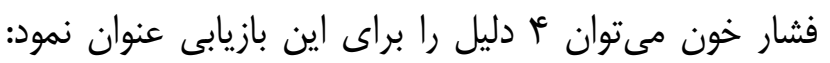

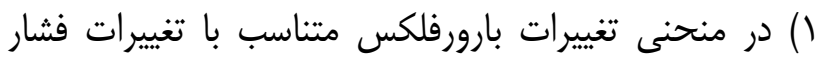

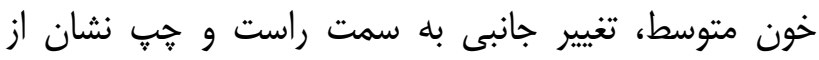

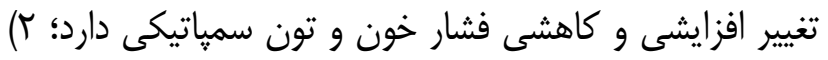
تغييرات بالايى و پإيينى فلات بالايى منحنى

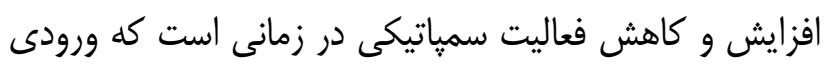

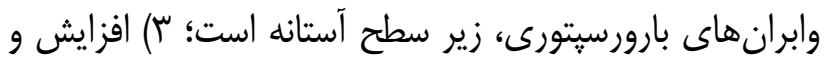
كاهش شيب حداكثرى منحنى، نشاندهنده افزايش و كاهش

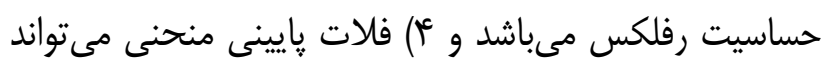

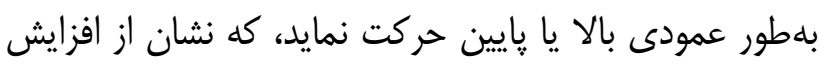

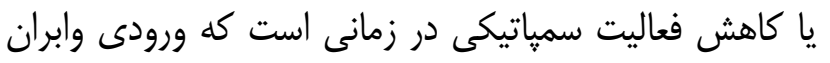

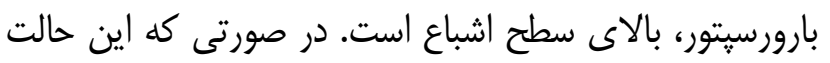

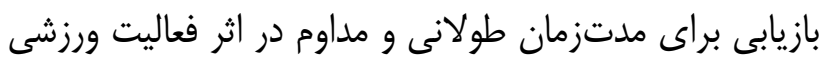
دهار تعديل كردد، باعث افزايش فعاليت پاراراسمياتيكى و واساسخ

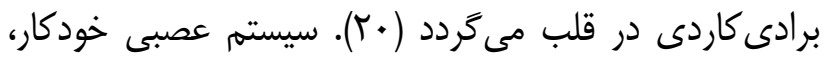

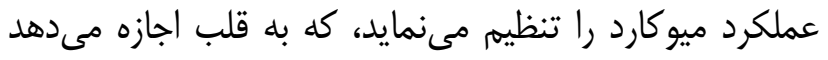

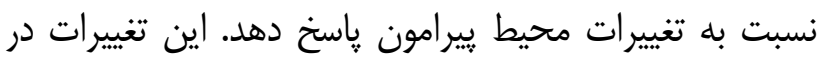




\section{منابع:}

1- Nagle EF, Sanders ME, Shafer A, Gibbs BB, Nagle JA, Deldin AR, Franklin BA, Robertson RJ. Energy expenditure, cardiorespiratory, and perceptual responses to shallow-water aquatic exercise in young adult women. Phys Sportsmed. 2013; 41(3): 67-76. doi: 10.3810/psm.2013.09.2018.

2- Koenig J, Jarczok MN, Wasner M, Hillecke TK, Thayer JF. Heart rate variability and swimming. Sports Med. 2014; 44(10): 1377-91. doi: 10.1007/s40279-014-0211-9.

3- Hashimoto Y, Okamoto T. Acute effects of walking in water on vascular endothelial function and heart rate variability in healthy young men. Clin Exp Hypertens. 2019; 41(5): 452-9. doi: 10.1080/10641963.2018.1506468.

4- Shaffer F, Ginsberg JP. An overview of heart rate variability metrics and norms. Front Public Health. 2017; 5: 258. doi: 10.3389/fpubh.2017.00258

5- Al Haddad H, Laursen PB, Chollet D, Lemaitre F, Ahmaidi S, Buchheit M. Effect of cold or thermoneutral water immersion on post-exercise heart rate recovery and heart rate variability indices. Auton Neurosci. 2010; 156(1-2): 111-6. doi: 10.1016/j.autneu.2010.03.017.

6- Choo HC, Nosaka K, Peiffer JJ, Ihsan M, Yeo CC, Abbiss CR. Effect of water immersion temperature on heart rate variability following exercise in the heat. Kinesiol Int J Fundam Appl Kinesiol. 2018; 50(Suppl 1): 67-74.

7- Schnell I, Potchter O, Epstein Y, Yaakov Y, Hermesh H, Brenner S, Tirosh E. The effects of exposure to environmental factors on heart rate variability: An ecological perspective. Environ Pollut. 2013; 183: 7-13. doi: 10.1016/j.envpol.2013.02.005.

8- Sotiriou P, Kouidi E, Samaras T, Deligiannis A. Linear and non-linear analysis of heart rate variability in master athletes and healthy middle-aged non-athletes. Med Eng Phys. 2013; 35(11): 1676-81. doi:10.1016/j.medengphy.2013.06.003.

9- Iranpour A, Bolboli L. Evaluation of Heart Rate Fluctuations with Two Frequency and Time Domain Methods Following Aerobic Training in Academic Active Men. Scientific Journal of Nursing, Midwifery and Paramedical Faculty. 2019; 4(4): 30-45. [Persian]

10- Perini R, Milesi S, Biancardi L, Pendergast DR, Veicsteinas A. Heart rate variability in exercising humans: effect of water immersion. Eur J Appl Physiol Occup Physiol. 1998; 77(4): 326-32. DOI: 10.1007/s004210050341

11- Cornelissen VA, Verheyden B, Aubert AE, Fagard RH. Effects of aerobic training intensity on resting, exercise and post-exercise blood pressure, heart rate and heart-rate variability. J Hum Hypertens. 2010; 24(3): 175-82. doi: 10.1038/jhh.2009.51.

12- de Oliveira Ottone V, de Castro Magalhães F, de Paula F, Avelar NC, Aguiar PF, da Matta Sampaio PF, et al. The effect of different water immersion temperatures on post-exercise parasympathetic reactivation. PloS one. 2014; 9(12): e113730. doi: 10.1371/journal.pone.0113730.

13- Girona M, Grasser EK, Dulloo AG, Montani JP. Cardiovascular and metabolic responses to tap water ingestion in young humans: does the water temperature matter?. Acta Physiol (Oxf). 2014; 211(2): 358-70. doi: 10.1111/apha.12290.

14- Hoshi RA, Pastre CM, Vanderlei LC, Godoy MF. Poincaré plot indexes of heart rate variability: relationships with other nonlinear variables. Auton Neurosci. 2013; 177(2): 271-4. doi: 10.1016/j.autneu.2013.05.004.

15- Reimers AK, Knapp G, Reimers CD. Effects of exercise on the resting heart rate: a systematic review and metaanalysis of interventional studies. J Clin Med. 2018; 7(12): 503. doi: 10.3390/jcm7120503.

16- Kaviani H, Mousavi AS. Psychometric properties of the Persian version of Beck Anxiety Inventory (BAI). Tehran Univ Med J. 2008; 66(2): 136-40. [Persian]

17. Moon JR, Tobkin SE, Smith AE, Lockwood CM, Walter AA, Cramer JT, et al. Anthropometric estimations of percent body fat in NCAA Division I female athletes: a 4-compartment model validation. J Strength Cond Res. 2009; 23(4): 1068-76. doi: 10.1519/JSC.0b013e3181aa1cd0. 
18- Saur J, Leweling H, Trinkmann F, Weissmann J, Borggrefe M, Kaden JJ. Modification of the Harris-Benedict equation to predict the energy requirements of critically ill patients during mild therapeutic hypothermia. In Vivo. 2008; 22(1): 143-6.

19- Kanitz AC, Delevatti RS, Reichert T, Liedtke GV, Ferrari R, Almada BP, et al. Effects of two deep water training programs on cardiorespiratory and muscular strength responses in older adults. Exp Gerontol. 2015; 64: 55-61. doi: 10.1016/j.exger.2015.02.013.

20- Raffaelli C, Galvani C, Lanza M, Zamparo P. Different methods for monitoring intensity during water-based aerobic exercises. Eur J Appl Physiol. 2012; 112(1): 125-34. doi: 10.1007/s00421-011-1963-7.

21- Zaccolo M. cAMP signal transduction in the heart: understanding spatial control for the development of novel therapeutic strategies. British journal of pharmacology. 2009 Sep;158(1):50-60. doi: 10.1111/j.14765381.2009.00185.x. 